\title{
The Algorithmic Narrator ${ }^{\dagger}$
}

\author{
Paolo Sordi \\ Department of Humanistic Studies, University of Rome Tor Vergata, Via Columbia 1, 00133 Rome, Italy; \\ paolo.sordi@uniroma2.it; Tel.: +39-06-72595106 \\ + Presented at the IS4SI 2017 Summit DIGITALISATION FOR A SUSTAINABLE SOCIETY, Gothenburg, \\ Sweden, 12-16 June 2017.
}

Published: 8 June 2017

\section{Introduction}

Facebook promises to make us readers and authors of our own stories, but in fact, Mark Zuckerberg's social network has created a production line of narratable narration that imprisons lives, biographies, and possible tales. Processing the metadata, behaviors and interactions of billions of users within the platform's walled garden, the algorithm imposes itself as an omniscient and totalitarian narrator, a predictive storytelling machine that benefits the only readers that truly count: advertisers.

In light of reflections (among others) from Christian Salmon, James Gottschall, Raul Mordenti, and Marie-Laure Ryan, and based on the visible concentration in new media of the dual role of content providers and providers of distribution infrastructures [1], in this paper I will argue that Facebook's narrative dictatorship overrides the Web as a space for open, collaborative and groundup participatory narration. All that remains of the original hypertextual architecture is a television network, a broadcasting platform that favors orality, video and slideshows in such a way that gurus of innovation and the digital world become the new pop stars of our neoliberal era through Ted stages and YouTube videos.

\section{Algorithmic Curation}

Facebook's news feed has always been seen as an aggregator: an automated editor that chooses what to include and what to exclude in its users' feeds, selecting from a flow of content from friends, favorite brands, news sources, as well as what form of content to promote when including content (video, photos, text, links). But algorithmic curation [2] is only the tip of the iceberg. With content and data generated both knowingly and unknowingly by users - a limitless army of little unwitting writer-laborers-Facebook rewrites our story, making their version more "true" than the one that we think we are writing on the platform every day, a platform that knows us better than we know ourselves. For the Washington Post, Caitlin Dewey collected a list of everything that the social network knows about its users: age, sex, language, level of education, salary, relationship status, property value, credit card, willingness to make purchases and what type of purchases, use of coupons, vacations. The list goes on to include 98 points, including alcohol consumption and medicines purchased [3].

It is not an editor's morbid curiosity that wants to offer its users the "best possible experience on the platform", as goes one of the recurring mantras of social media gurus. Reconstructing the functioning mechanism of television dominated by the "advertising gods", Raul Mordenti clarifies that just as the exchange that gives life to a television program is not between a producer and the audience, the ruling agreement is between the producer and the advertiser. Up for sale is the audience, the target of the advertiser that increases the opportunity for profit of investing companies, and consequently, the chance to live (or continue living) of the program itself [4]. 


\section{The Totalitarian Narrative Machine}

For advertisers, the only readers that truly count, Facebook is more than an omniscient narrator, it is an algorithmic narrator, that uses the strength of its own algorithm to generate daily stories that are updated based on the behaviors of users/authors/characters and the software's settings. It is the interactive narrative machine that Marie-Laure Ryan imagined would be able to produce on-the-fly stories with every iteration of the program [5]. A narrative machine, both omniscient and totalitarian: within Facebook's walled garden, conditions of interaction with the platform are non-negotiable, just as is control over one's "authentic" biography.

In The Orphan Master's Son, a novel by Adam Johnson set in Kim Jong Il's despotic North Korea, the regime imprisons rebels, tortures them with electric shock and charges a prison guard with redirecting a prisoner's biography in a way that conforms his existence with the dictatorship's core values [6]. When an absolute power exists, stories and lives do not belong to people, and narration must prevail over life. If the opposite were true, if men destined to read and listen (and post on social media) were not limited to following a script that others had written, even those men could become narrators and build a new narration. Then narration would depend on people. We are storytelling machines, after all, as Jonathan Gottschall reminds us, especially regarding our own lives, modelled according to a strategic and refined narrative elaboration that selects fragments of memories and experiences in a reconstruction that is as true as it is plausible [7].

\section{Facebook Factory}

The big trick of Facebook lies here, in offering a writing system that promises to make us authors of a story where the hero lives an interesting life, led by intriguing and fun private events, immersed in the facts and conflicts of the global world. Everything, both private and public, both stories and history, is made up of the newsfeed's narration. The social network is the dematerialized version, to the benefit of the "web community", of stages, of keynote speeches, of town halls, to propagate the studied charisma of the Silicon Valley types and a narrative rapture of their innovation epic: an identifiable character that speaks to us from a surrogate stage within an egalitarian community, the live viewing of the story substituted by intensive use of photos and videos that multiply opportunities to be involved, the innate believability in the story's everyday qualities, taking place before our eyes, scroll after scroll.

The only thing is that all users, Gottschall's storytellers, work for the Facebook Factory. They devour content while Zuckerberg's algorithm builds an assembly line of "narratable narration" that imprisons, rather than domesticates, the stories liberated from hypertext and handed over to a market regime that takes complete control in a cycle of legitimization that, from YouTube videos to Google searches and Apple's iPhones, always manages to come full circle. The monopolistic intention of the competing platforms is not about ideologies in conflict, it is about users.

\section{Conclusions}

If hypertext and the Web offered a pact to authors, a divesture of a part of their power in exchange for a dynamic increase in ways to produces sense and stories, open and collective narration with ground-up participation [8], Facebook proclaimed its rules from above, on a massive scale. Among such rules are terms and conditions which are unmodifiable and unmoved by hypertext. On Facebook, the hypertext link disappears once and for all; references to other pages, additional content, both on and off the platform, are only possible through incorporating them in a post, which in any case does not accept more than one. Writing links, building well-constructed connections and imagining stories that are pertinent to one another is now left exclusively to Zuckerberg's algorithm, in an evident negation of collective participation in narration, leaving a mere aggregative illusion. For collective digital narration that is open to contribution from all the network's participants to become true stories, there must be, as Scott Rettberg claims [9], an editor (or an editorial system) that is able to provide structure for the endeavor. Additionally, the wider the collaboration from the web, the more limits must be defined regarding which individual contributions should be accepted. 
From this point of view, Facebook is the editor in chief, the dictator that does not accept stories from outside its limits and rules. With a distracted click, users submit themselves, simultaneously unaware, conscious and proactive, to the algorithm's invisible narration, with its attractive force in its ability to provide the semblance of organization within the web's disorienting chaos. A cage where mass-production, repetition, habits and ticks build a reassuring tale within a community of users who only think they are sharing a life, when the only thing it has in common, to paraphrase Christian Salmon [10], are smartphone apps processed by the same media circuit, the algorithm.

Conflicts of Interest: The author declares no conflict of interest.

\section{References and Notes}

1. Labovitz, C.; lekel-Johnson, S.; McPherson, D.; Oberheide, J.; Jahanian, F. Internet Inter-Domain Traffic. 2010. Available online: https://jon.oberheide.org/files/sigcomm10-interdomain.pdf (accessed on 1 december 2016).

2. DeVito, M.A. From Editors to Algorithms. Digit. J. 2016, 1-21, doi:10.1080/21670811.2016.1178592.

3. Dewey, C. 98 Personal Data Points That Facebook Uses to Target Ads to You. In The Washington Post; 19 August 2016. Available online: https://www.washingtonpost.com/news/the-intersect/wp/2016/08/19/98personal-data-points-that-facebook-uses-to-target-ads-to-you/ (accessed on 2 February 2017).

4. Mordenti, R. L'altra Critica; Meltemi Editore: Roma, Italy, 2007.

5. Ryan, M.-L.; Thon, J.-N.; Harvey, C.B.; Harvey, C.B. Storyworlds across Media: Toward a Media-Conscious Narratology; University of Nebraska Press: Lincoln, NE, USA, 2014.

6. Johnson, A. The Orphan Master's Son: A Novel; Random House: New York, NY, USA, 2012.

7. Gottschall, J. The Storytelling Animal: How Stories Make Us Human; Houghton Mifflin Harcourt: Boston, MA, USA, 2012.

8. Rosenberg, S. Say Everything: How Blogging Began, What It's Becoming, and Why It Matters; Crown: New York, NY, USA, 2010.

9. Rettberg, S. All Togeteher Now: Hypertext, Collective Narratives, and Online Knowledge Communities. In New Narratives: Stories and Storytelling in the Digital Age; Page, R., Thomas, B., Eds.; University of Nebraska Press: Lincoln, NE, USA, 2011.

10. Salmon, C. Storytelling. La Machine à fabriquer les Images et à formater les Esprits; La Découverte: Paris, France, 2007.

(C) 2017 by the author. Licensee MDPI, Basel, Switzerland. This article is an open access article distributed under the terms and conditions of the Creative Commons Attribution (CC BY) license (http://creativecommons.org/licenses/by/4.0/). 